\title{
ASSESMENT OF DIFFERENT NON-HOST CROPS AS TRAP CROP FOR REDUCING OROBANCHE AEGYPTIACA PERS. SEED BANK
}

\author{
Bipana Devi Acharya \\ Department of Botany \\ Amrit Science Campus, Tribhuvan University, Kathmandu, Nepal \\ E-mail: bipanaacharya@gmail.com
}

\begin{abstract}
Experiments were performed in pot and field conditions to evaluate effects of non-host crops on Orobanche seed bank. The two sites chosen for the study were located in highly Orobanche infested areas of Nawalparasi district, an inner Terai region of central Nepal. Pot and field experiments were conducted in the soil naturally infested with Orobanche seeds. Altogether, 21 different non-host crop species were tested in the study. Orobanche seed density in soil samples collected from pot/plot before planting and after harvest of each crop species was recorded. Data of pre-plant and postharvest were compared in order to assess the effects of the test crops on Orobanche seed density. On the basis of degree of effects on the Orobanche seed bank, the investigated crop species could be classified in to three categories: (a) non-potential trap crop: garlic, chilli, coriander, carrot, buckwheat, sunflower, french bean, pea, egg plant, potato, fenugreek, wheat and faba bean; (b) moderately potential trap crop: barley, onion, chickpea and maize; and (c) highly potential trap crops: radish, lentil, linseed, fennel and cumin.
\end{abstract}

Key words: Orobanche aegyptiaca, trap crop, seed bank, germination.

\section{INTRODUCTION}

Orobanche is a serious root holoparasite of many economically important dicotyledonous plants. It is a threat to about 16 million hectares of arable land in the mediterranean region and west Asia (Sauerborn 1991). They are very difficult to control due to their high seed production up to 500000 seeds/plant in $O$. crenata (Cubero and Moreno 1979). The seeds are very small (0.25$0.35 \mathrm{~mm}$ ) and can remain viable possibly up to 20 years in soil in absence of suitable host (Cubero and Moreno 1979, Puzzilli 1983, Kadry and Tewfic 1956). The fruit is a capsule containing
1200-1500 small, dark grey seeds. This serves as a source of infestation for the crops in the following years. This results in building of persistent seed bank of Orobanche making its eradication difficult (Foy et al. 1989). In Nepal, it has been a constraint in the production of two important cash crops namely, tori (Brassica campestris var. toria) and tobacco (Nicotiana tabaccum) crops (Rao et al. 1988, Jacobsohn et al. 1989).

Many non-host plants can stimulate the germination of Orobanche seeds (Brown et al. 1951, Krishnamurthy et al. 1977, Abbes et al. 2008). Root exudates from flax (Linum 
usitatissimum L.), and corn (Zea mays L.), which are not host of $O$. minor can stimulate the seed germination more than that of clover (Trifolium repens L.), which is a normal host (Brown et al. 1952). The use of trap crops and catch crops is one of the best methods currently available to control agricultural root parasites (Sauerborn 1991). It is hypothesized that trap crops or non- host plants stimulate the germination of the parasite seed but cannot be infected and thus reduces seeds in the soil due to suicidal germination. In the present study, an attempt has been made to find out the effects of different non-host crops on the seed bank of the $O$. aegyptiaca in naturally infested soil.

\section{MATERIALS AND METHODS}

Experiments were conducted in pots and two fields at site A (Vedabari) and site B (Beldia) in the Nawalparasi District, an Inner Terai region of Nepal, where infection of the Orobanche sp. was fairly high. The district is situated at about 153 $\mathrm{Km}$. South-West to Kathmandu Valley. Both sites are farmer's fields hired for tori growing season.

Pot experiments were carried out at Site-A to study the effect of different non-host crops on seed bank of $O$. aegyptiaca. Altogether, 22 winter crops were tested (Table 1). Pot mixture included: a) soil collected from naturally infested field by Orobanche seeds, b) Fertilizers (N-0.8g/kg, P $1.2 \mathrm{~g} / \mathrm{kg}$ and $\mathrm{K} 0.6 \mathrm{~g} / \mathrm{kg}$ of soil) and, c) compost. The earthen pots of size 9 inches diameter were first moistened with water and then filled with soil mixture. About $3 / 4^{\text {th }}$ of pots were buried into the soil to avoid rapid fluctuation of soil temperature and moisture.

Seeds or seedlings of test crops were collected from the local market. Crop seeds were sown 3-4 $\mathrm{cm}$ deep in the soil. Tubers of potato, bulb-lets of garlic and, seedlings of onion, egg plants and that of chili were planted in the pots. The number of the seeds sown for the pot experiments and the final number of plants that were maintained for the experiment are given in Table 1. To avoid dehydration of the germinating seeds, pots were covered with thin layer of straw and regular watering was done. The straw cover was removed when seedlings were shown up. There were three replications for each treatment, including control pots. Soil samples for quantitative estimation of Orobanche seeds were collected from each pot at the time of crop sowing and after harvest.

Field experiments were conducted in the rainfed fields at Site A and Site B, with maize and tori as summer and winter crops, respectively. The field had homogenous nutrient and moisture regimes. The soil type in field A was sandy-loam with $71 \%$ sand, $22 \%$ silt, $7 \%$ clay and $2.01 \%$ total organic matters. Soil nitrogen was $0.151 \%$, phosphorus $189 \mathrm{~kg} / \mathrm{ha}$, potassium $516 \mathrm{~kg} / \mathrm{ha}$, and the soil $\mathrm{pH}$ was 6.2. Manuring was done with animal dung. Unlike the Field-A, the soil type in Field-B was loam with $49 \%$ sand, $30 \%$ silt, $21 \%$ clay and $2.28 \%$ total organic matters. Nitrogen was $0.132 \%$, Potassium $724 \mathrm{~kg} / \mathrm{ha}$, and Phosphorous $161 \mathrm{~kg} / \mathrm{ha}$. The soil $\mathrm{pH}$ was 6.7. The mean soil temperature of experimental areas varied from $12^{\circ} \mathrm{C}$ to $23^{\circ} \mathrm{C}$ in the morning (at $6 \mathrm{am}$ ) and from $15^{\circ} \mathrm{C}$ to $25^{\circ} \mathrm{C}$ in the afternoon (at $1 \mathrm{pm}$ ) during the study period.

The fields were ploughed twice with tractor supported with disc harrow two weeks before final preparation, i.e., at the second week of September. The field has randomized complete block design with 22 treatments including control. The plot area in Field-A was $2.4 \times 2.6 \mathrm{~m}$ and it was $2.4 \times 3.6 \mathrm{~m}$ in Field-B. There were three replications for each treatment.

The seeds/seedlings/bulblets/tubers of 22 test crops obtained from local market were planted after the final preparation of the field in first week of October. Plots were irrigated a day before sowing. Later irrigation was done as required. Soil was sampled two times from each plot: first before sowing and, the second after harvest. The sampling 
Table 1. List of winter crop plants, their number sown/pot and number maintained/pot, for screening their efficiency in reducing $O$. aegyptiaca seed bank in soil.

\begin{tabular}{|c|c|c|c|}
\hline Crops tested (Botanical name) & Common name & Seeds sown/pot & Plants maintained/pot \\
\hline Allium cepa $\mathrm{L} . * *$ & Onion & 3 & 1 \\
\hline Allium sativum L.*** & Garlic & 3 & 2 \\
\hline Capsicum frutescens L.** & Chilli & 3 & 1 \\
\hline Cicer arietinum $\mathrm{L} . *$ & Chickpea & 5 & 3 \\
\hline Coriandrum sativum L.* & Coriander & 10 & 5 \\
\hline Cuminum cyminum L.* & $\mathrm{Cumin}^{+}$ & 10 & 5 \\
\hline Daucas carrota L.* & Carrot & 10 & 3 \\
\hline Fagopyrum esculentum Moench* & Buckwheat & 5 & 2 \\
\hline Foeniculum vulgare Mill.* & Fennel & 10 & 5 \\
\hline Helianthus annus L.* & Sunflower & 3 & 1 \\
\hline Hordeum vulgare L.* & Barley & 7 & 3 \\
\hline Lens culinaris Medic.* & Lentil & 7 & 3 \\
\hline Linum usitatissimum L.* & Linseed & 7 & 3 \\
\hline Phaseolus vulgaris L.* & French bean & 3 & 1 \\
\hline Pisum sativum L.* & Pea & 5 & 3 \\
\hline Raphanus sativus L.* & Radish & 5 & 2 \\
\hline Solanum melongena L.** & Egg plant & 2 & 1 \\
\hline Solanum tuberosum L.*** & Potato & 3 & 1 \\
\hline Trigonella foenum graecum L.* & Fenugreek & 10 & 5 \\
\hline Triticum aestivum L.* & Wheat & 7 & 3 \\
\hline Vicia faba L.* & Faba bean & 5 & 3 \\
\hline Zea mays L.* & Maize & 3 & 1 \\
\hline
\end{tabular}

*Seed, **Seedling, *** Bulb-let, **** Tuber, + Tested in pot only

spots were located between plant rows and there were three equally spaced spots between rows. Soil was sampled using auger reaching up to $15 \mathrm{~cm}$ deep. One $\mathrm{Kg}$ of Soil was sampled from different spots of a plot using composite soil sampling technique for laboratory estimation of Orobanche seeds. The percentage reductions of Orobanche seeds were determined from the difference of initial Orobanche seed count before sowing and final Orobanche seed count after harvest. The number of the Orobanche seeds in the soil was estimated with method of Ashworth (1976) with some modification (Acharya 2002, Acharya et al. 2003).

\section{RESULTS}

Comparison of seed bank in soil before sowing and after harvest of different test crops showed that the number of Orobanche seeds reduced in all cases, even in fallow pots or plots (controls).

\section{Pot experiment}

The number of Orobanche seeds/100 g soil before sowing and after harvest of different test crops including control pots is presented in Fig. 1 which shows that there is a reduction in number of Orobanche seeds in most of the test crops. The percentage of Orobanche seed in the study reduced from $11.64 \pm 0.84$ to $54.27 \pm 8.63$ with an average of $24.43 \pm 11.17 \%$ (Table 2). 


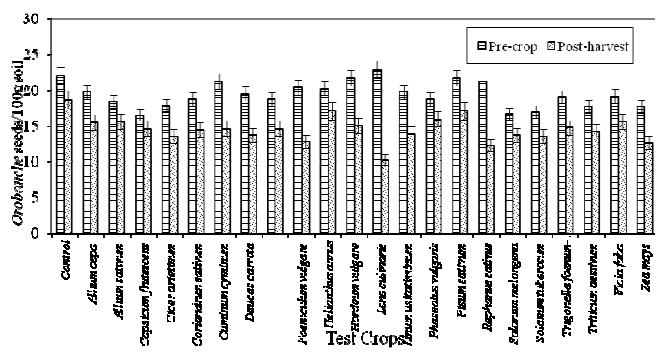

Fig. 1. Number of Orobanche seeds/100 g soil at the time of pre and post harvest of different test crops in pot experiments.

Of the 22 crops investigated (Fig. 1), the reduction of Orobanche seed bank was found to be significant $(\mathrm{P}=0.05)$ compared to control pots in cumin, carrot, fennel, barley, lentil, linseed, radish and maize (Table 2). The reduction was highest in lentil (54.27 \pm 8.63$)$.

Test crops like onion, chickpea, coriander, buckwheat, pea, brinjal, potato, fenugreek, wheat, and faba bean reduced Orobanche seed density from $17.68 \pm 10.95$ to $23.64 \pm 2.99 \%$. Furthermore, the reduction of seed density of the parasite was fairly low in crops like garlic, chili, sunflower and french bean, which ranged from 11.64 to $15.15 \%$. The values of reduction were statistically insignificant compared to the reduction in control pots.

\section{Field A}

Number of Orobanche seeds $/ \mathrm{m}^{2}$ of plots before and after harvest of different test crops of the Field-A is given in Fig. 2. Out of 21 test crops investigated, seed bank was reduced significantly $(\mathrm{P}=0.05)$ in onion, chickpea, radish, fennel, lentil and linseed than in control plots. Plots with coriander, carrot, buckwheat, sunflower, barley, pea, egg plant, potato, fenugreek, wheat, and maize (Fig. 2) showed reduction in Orobanche seed density but insignificantly at $\mathrm{P}=0.05$ when compared with control plots. The percentage reduction of Orobanche seeds in test crops like garlic, chili, french bean and faba mean were more or less same as in control plots, hence showed same groupings in Duncan's multiple range tests followed after ANOVA (Table 2).

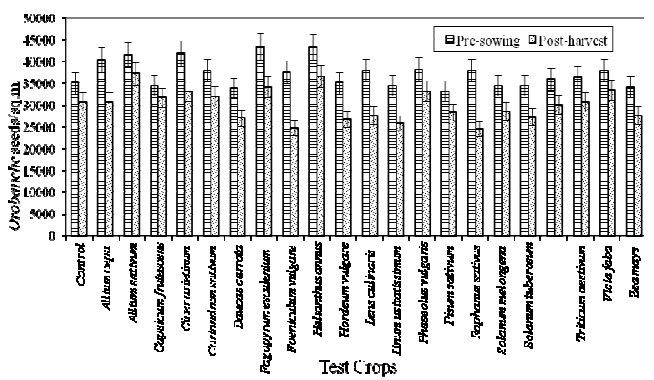

Fig. 2. Number of Orobanche seeds/sq $m$ at the time of pre and post harvest of different test crops in Field $A$ (Vedabari).

\section{Field B}

Number of Orobanche seeds $/ \mathrm{m}^{2}$ at pre-plant and post harvest of different test crops in the field are shown in Fig. 3. The mean reduction in Orobanche seed bank in this field was found to be $19.24 \pm 7.62 \%$ and the reduction was highest in lentil (35.39 $\pm 1.83 \%$.) and lowest in chili $(6.41 \pm 5.28 \%)$. Out of 21 crops investigated, Orobanche seed bank was reduced significantly $(\mathrm{P}=0.05)$ in fennel, lentil, linseed, radish and barley compared to control plots (Table 2).

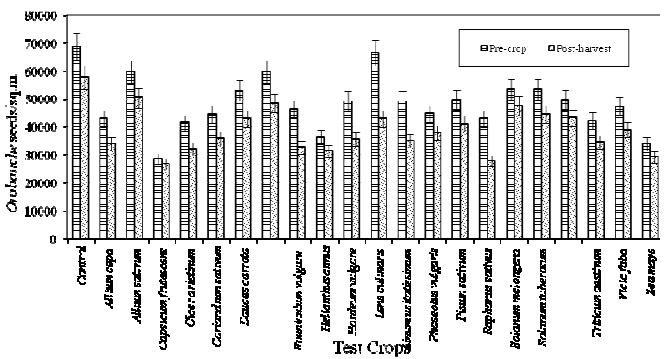

Fig. 3. Number of Orobanche seeds/sq $m$ at the time of pre and post harvest of different test crops in Field B (Beldia).

ECOPRINT VOL 19, 2012 
Table 2. Reduction (\%) of seed density of $O$. agyptiaca in different test crops grown in pots, Field $A$ and Field B. Same letters followed after the mean \pm standard deviation in a column do not differ significantly at $\mathbf{P}=\mathbf{0 . 0 5}$ according to Duncan's Multiple range tests followed after ANOVA.

\begin{tabular}{|c|c|c|c|c|}
\hline \multirow[t]{2}{*}{ Tested Crops } & \multirow{2}{*}{$\begin{array}{l}\text { Common } \\
\text { name }\end{array}$} & \multicolumn{3}{|c|}{ Reduction $(\%)$ in seed density (Mean \pm Sd) } \\
\hline & & Pot expt & Field A & Field B \\
\hline Allium cepa $\mathrm{L}$. & Onion & $22.00 \pm 3.78 \mathrm{ABCD}$ & $23.73 \pm 3.00 \mathrm{CDEFGH}$ & $17.33 \pm 9.99 \mathrm{ABCD}$ \\
\hline Allium sativum $\mathrm{L}$. & Garlic & $15.15 \pm 5.08 \mathrm{~A}$ & $10.47 \pm 1.51 \mathrm{AB}$ & $13.47 \pm 6.80 \mathrm{AB}$ \\
\hline Capsicum frutescens $\mathrm{L}$. & Chili & $11.64 \pm 0.84 \mathrm{~A}$ & $8.20 \pm 3.16 \mathrm{~A}$ & $6.41 \pm 5.28 \mathrm{~A}$ \\
\hline Cicer arietinum $\mathrm{L}$. & Chickpea & $23.64 \pm 2.99 \mathrm{ABCD}$ & $20.72 \pm 5,15$ BCDEFG & $22.40 \pm 5.81 \mathrm{BCDE}$ \\
\hline Coriandrum sativum $\mathrm{L}$. & Coriander & $22.41 \pm 3.69 \mathrm{ABCD}$ & $17.25 \pm 7.84 \mathrm{ABCDEF}$ & $19.73 \pm 4.96 \mathrm{ABCD}$ \\
\hline Cuminum cyminum $\mathrm{L}$ & Cumin & $31.29 \pm 8.98 \mathrm{DE}$ & - & - \\
\hline Daucas carrota $\mathrm{L}$. & Carrot & $29.53 \pm 5.47 \mathrm{BCDE}$ & $19.44 \pm 5.85 \mathrm{ABCDEF}$ & $18.98 \pm 9.91 \mathrm{ABCD}$ \\
\hline Fagopyrum esculentum Moench & Buckwheat & $21.86 \pm 8.64 \mathrm{ABCD}$ & $19.17 \pm 3.63 \mathrm{ABCDEF}$ & $19.89 \pm 7.84 \mathrm{ABCD}$ \\
\hline Foeniculum vulgare Mill. & Fennel & $37.33 \pm 5.91 \mathrm{EF}$ & $31.01 \pm 9.58 \mathrm{GH}$ & $28.83 \pm 9.56 \mathrm{DEF}$ \\
\hline Helianthus annus $L$. & Sunflower & $14.62 \pm 9.16 \mathrm{~A}$ & $14.22 \pm 7.64 \mathrm{ABCDE}$ & $14.09 \pm 7.68 \mathrm{AB}$ \\
\hline Hordeum vulgare $\mathrm{L}$. & Barley & $31.33 \pm 8.58 \mathrm{DE}$ & $24.22 \pm 6.24 \mathrm{DEFGH}$ & $27.89 \pm 9.62 \mathrm{CDEF}$ \\
\hline Lens culinaris Medic. & Lentil & $54.27 \pm 8.63 \mathrm{G}$ & $26.93 \pm 6.34 \mathrm{FGH}$ & $35.39 \pm 1.83 \mathrm{~F}$ \\
\hline Linum usitatissimum $\mathrm{L}$. & Linseed & $30.05 \pm 2.84 \mathrm{CDE}$ & $25.36 \pm 7.51 \mathrm{EFGH}$ & $29.26 \pm 4.64 \mathrm{DEF}$ \\
\hline Phaseolus vulgaris L. & French bean & $14.49 \pm 5.33 \mathrm{~A}$ & $12.59 \pm 6.20 \mathrm{ABCD}$ & $15.08 \pm 3.28 \mathrm{ABC}$ \\
\hline Pisum sativum L. & Pea & $20.56 \pm 3.38 \mathrm{ABCD}$ & $15.08 \pm 2.37 \mathrm{ABCDEF}$ & $17.45 \pm 8.26 \mathrm{ABCD}$ \\
\hline Raphanus sativus L. & Radish & $42.28 \pm 5.29 \mathrm{~F}$ & $34.69 \pm 9.09 \mathrm{H}$ & $34.96 \pm 5.00 \mathrm{EF}$ \\
\hline Solanum melongena $\mathrm{L}$. & Egg plant & $17.68 \pm 10.95 \mathrm{AB}$ & $16.49 \pm 6.73 \mathrm{ABCDEF}$ & $11.31 \pm 4.60 \mathrm{AB}$ \\
\hline Solanum tuberosum $\mathrm{L}$. & Potato & $19.34 \pm 6.08 \mathrm{ABCD}$ & $20.73 \pm 3.15$ BCDEFG & $15.13 \pm 8.04 \mathrm{ABC}$ \\
\hline Trigonella foenum-graecum $\mathrm{L}$. & Fenugreek & $22.51 \pm 0.69 \mathrm{ABCD}$ & $16.11 \pm 7.17 \mathrm{ABCDEF}$ & $12.08 \pm 9.16 \mathrm{AB}$ \\
\hline Triticum aestivum $\mathrm{L}$. & Wheat & $18.79 \pm 5.47 \mathrm{ABC}$ & $15.20 \pm 4.21 \mathrm{ABCDEF}$ & $16.98 \pm 9.01 \mathrm{ABCD}$ \\
\hline Vicia faba $\mathrm{L}$. & Faba bean & $18.04 \pm 5.67 \mathrm{AB}$ & $11.82 \pm 7.85 \mathrm{ABC}$ & $17.64 \pm 1.19 \mathrm{ABCD}$ \\
\hline Zea mays $\mathrm{L}$. & Maize & $28.05 \pm 6.70 \mathrm{BCDE}$ & $18.99 \pm 8.00 \mathrm{ABCDEF}$ & $13.66 \pm 4.89 \mathrm{AB}$ \\
\hline Control & & $15.09 \pm 3.47 \mathrm{~A}$ & $12.39 \pm 1.54 \mathrm{ABCD}$ & $15.40 \pm 3.02 \mathrm{ABC}$ \\
\hline
\end{tabular}

\section{DISCUSSION}

In the present study, it was interesting to note that there was some reduction in Orobanche seed bank in fallow (control) pots and plots. The reason (s) behind the reduction might be that the weed seed density is not only affected by the host stimulants but also by many other environmental factors, like rainfall, wind, tillage practices, kind of manure used, activities of soil animals (rodents and insects) and more importantly soil microorganisms (Lopez-Granados and Garcia-Torres 1993). In present study, the mass of isolated Orobanche seeds from infested soil samples contained a fair number of damaged seeds. Some of the damaged seeds were found infested with fungus (i), some empty (without embryo) and some broken (possibly devoured by soil insects). On the basis of the results obtained from seed bank study, the tested crops have been categorized into three groups: Non-potential, moderately potential, and highly potential trap crops, which are discussed below. 
Non potential trap crops: Among the tested crops, Garlic, Chilli, Coriander, Carrot, Buckwheat, Sunflower, French bean, Pea,Egg plant, Potato, Fenugreek, Wheat and Faba bean showed insignificant reduction in Orobanche seed bank. Though many of these crops like Garlic, French bean, Potato, egg plant, carrot, sunflower. faba beans has been described as trap crop for $O$. aegyptiaca (Foy et al 1989, Sauerborn 1991, Jacobshon et al 1980), but in present study it was unable to reduce its seed bank. The possible reason for this may be due to presence of different physiological races in $O$. aegyptiaca, which was also suspected by Jacobshon (personal communication).

Pea coriander, chilli and faba beans are described as trap crop for different species of Orobanche like O. cernua, O. mutely, O. crenata, O. minor (Krishnamurty et al 1977,Foy et al 1989 , Sauerborn 1991), hence was tested in the present study. But in the present study, insignificant reduction in the Orobanche seed bank proved these crops to be non-potential trap crops.

Fenugreek was used as a trap crop for controlling $O$. crenata in Vicia faba fields in a pilot experiment of crop rotation in Northwest locality of Nile delta, Egypt (Al-Menoufi 1991). Cultivation of Fenugreek with Vicia faba reduced emergence of $O$. crenata by $89.8 \%$, but in the present study, there was insignificant reduction in Orobanche seed bank in both fields after cultivation of fenugreek in comparison to fallow, indicating that it could not be a suitable trap crop.

Lins et al. (2006) have described Triticum aestivum L. (wheat) as a false host of $O$. minor and reported 20-70\% seed germination in growth chamber experiments. But in the present study, the percentage reduction in O. aegyptiaca seeds in soil after cultivation of wheat was insignificantly different than reduction in control. Results obtained from pot experiment and field experiment in the present study support the view of $\mathrm{Abu}$
Irmaileh (1994) that there is no possibility of using wheat in rotation as a trap crop for $O$. aegyptiaca.

Moderately potential trap crops: On the basis of seed bank study in pots and fields, Hordeum vulgare L. (Barley), Allium cepa L. (Onion) Cicer arietinum L. (Chickpea) and Zea may L. (Maize) have been identified as moderately potential trap crops. Three crops Allium cepa L., Cicer arietinum L. and Zea may L. showed inconsistent results in pot and field experiments. But Hordeum vulgare showed consistent results in all experiments. Hence, out of 4 crops Hordeum vulgare can be considered the best moderate potential trap crop.

Hordeum vulgare L. (Barley) was found to be an occasional host of $O$. aegyptiaca while studying host range of different Orobanche species in Nepal (Khattri et al 1991). Results obtained in pot and field studies were encouraging as there was a significant increase in reduction $(\mathrm{P}=0.05)$ of Orobanche seed density, and not a single plant was found to be parasitized. Therefore, role of barley in crop rotation as trap crop for Orobanche seed bank reduction shows good promises because this is one of the traditional winter crops in Orobanche infested areas in Nepal.

Highly potential trap crops: On the basis of seed bank study, the crops like Radish, Fennel, Lentil Linseed and Cumin have been identified as highly potential trap crops. Radish, Fennel, Lentil, Linseed showed significant reduction in Orobanche seed density (both in pots and plots), and only a couple of radish were found associated with adult parasite. Khattri (1997) described lentil as a rare host of O. aegyptiaca in Nepal. This study supports the finding of many workers like Acharya (2002), Sauerborn (1991), Krishnamurty et al. (1977), Kleifeld et al. (1994), Schnell et al. (1994), Al-Menoufi (1991). It becomes evident from the above findings that these crops are highly effective to induce seed germination of $O$. aegyptiaca but is not, usually parasitized showing a true character to be an ideal trap crop. 
Cumin was able to reduce $21.7 \%$ seed bank of O. crenata in pot experiment (Schnell et al. 1994) but there is no information available regarding the testing of the crop plants with $O$. aegyptiaca. In the present study cumin was only tested in pot experiment in which seed bank reduced significantly $(\mathrm{P}=0.05)$ than that of control (fallow). As cumin was not tested in the field experiments, hence it needs further investigation.

\section{CONCLUSIONS}

Pot and field investigations for trap crop have clearly indicated that crops like radish (Raphanus sativus), lentil (Lens culinaris), linseed (Linum usitatissimum) and fennel (Foeniculum vulgare) ranked highest among the crops which reduce Orobanche seed bank significantly. Except the fennel, other three crops could successfully be incorporated as trap crops in the crop rotation in our agronomic conditions.

On the basis of results obtained from Orobanche seed bank study in pot and field conditions, the investigated crop species could be listed in one of the following three categories: (i) Non-potential trap crop: Garlic, chilli, coriander, carrot, buckwheat, sunflower, french bean, pea, egg plant, potato, fenugreek, wheat and faba bean. (ii) Moderately potential trap crop: Barley, onion, chickpea and maize. (iii) Highly potential trap crops: Radish, lentil, linseed, fennel and cumin (tested in pots only)

\section{ACKNOWLEDGEMENTS}

The author thanks to AMS Baniya, Department of Botany, Amrit Campus, Tribhuvan University, Kathmandu, for providing laboratory facilities during this work, and would also like to thank to Dr G.B. Khattri, Prof. S.C. Srivastava, Dr A. Bista and Dr. M.K Chettri for their valuable suggestions.

\section{REFERENCES}

Abbes, Z.Z., M. Kharrat and W. Chaibi. 2008. Seed germination and tubercle development of Orobanche foetida and O. crenata in presence of different plant species. Tunisian Journal of Plant Protection 3(2):101-109.

Abu Irmaileh, B.E. 1994. Nitrogen reduces branched broomrape (Orobanche ramosa) seed germination. Weed Science 42:57-60.

Acharya, B.D. 2002. Studies on control of Orobanche aegyptiaca Pers. by crop rotation using trap and catch crops. Ph.D. thesis submitted to Department of Botany, BRA Bihar University, Muzaffarpur, India.

Acharya, B.D., A. Bista, G.B. Khattri, M.K. Chettri and S.C. Srivastava. 2003. A method of quantitative estimation of Orobanche seeds from infested soil and its reliability test. Ecoprint 10(1):53-57.

Al-Menoufi, O.A. 1991. Crop rotation as a control measure of Orobanche crenata in Vicia faba fields. In: Progress in Orobanche Research. (eds.) Wegmann, K. and L.J. Musselman. Eberhard-Karls-Universitat, Tubingen, FRG pp. 241-247.

Ashworth, L.J. 1976. Quantitative detection of branched broomrape in California tomato soils. Plant Disease Reporter 60:380-383.

Brown, R., A.D. Greenwood, A.W. Johnson, A.G. Long and A.R. Lansdowne. 1951. Theee stimulant involved in the germination of Orobanche minor Sm. Chromatographic purification of crud concentrates. Journale of Biochemistry 48:564-574.

Brown, R., A.D. Greenwood, A.W. Johnson, A.G. Long, A.R. Lansdowne and N. Sunderland. 1952. The orobanche germinationfactor.3. Concentration of the factor by counter current distribution. Biochem. J. 52(4):571-574. 
Cubero, J.I. and M.T. Moreno. 1979. Agronomic control and sources of resistance in Vicia faba to Orobanche spp. In: Some current researches on Vicia faba in Western Europe. (eds.) Bond, D.A., G.T. Scarascia Mugnozza and M.H. Poulsen. Commission of The European Communities. pp. 41-80.

Foy, C.L, R. Jain and R. Jacobsohn. 1989. Recent approaches for chemical control of broomrape (Orobanche spp.). Rev. Weed Science 4:123152.

Jacobshon, R., A. Greenberger, J. Katan, M. Levi and H. Alon. 1980. Control of Egyptian broomrape (Orobanche aegyptiaca) and other weeds by means of solar heating of the soil by polyethylene mulching. Weed Science 28:312318.

Jacobsohn, R., V.P. Agrawal and G.B. Khattri. 1989. Studies on Broomrape (Orobanche spp.): Avoidance and Control. Fourth progress report to USAID-Israel CDR programme.

Kadry, A.R. and H. Tewfic. 1956. Seed germination in Orobanche crenata Forsk. Svensk Bot. Tidskr. 50:270-286.

Khattri, G.B. 1997. Some studies on biology and control of Orobanche in Brassica crops. A Thesis submitted for the Degree of Doctor of Philosophy in Botany (Faculty of Science) to the B.R.A. Bihar University Muzaffarpur, Bihar, India.

Khattri, G.B., P.K. Jha, V.P. Agarwal and R. Jacobsohn. 1991. Distribution, host range and phenology of Orobanche spp. in Nepal. In: Progress in Orobanche Research. (eds.) Wegmann, K. and L.J. Musselman. EberharKarls-Universitat, Tubingen, FRG. pp. 18-23.

Kleifeld, Y., Y. Goldwasser, G. Herzlinger, D.M. Joel, S. Golan and D. Kahana. 1994. The effects of flax (Linum usitatissimum L.) and other crops as trap and catch crops for control of Egyptian broomrape (Orobanche aegyptiaca Pers.). Weed Research. 34:37-44.

Krishnamurty, G.V.G., R. Lal and K. Nagarjan. 1977. Further studies on the effect of various crops on the germination of Orobanche seed. PANS 23:206-208.

Lins, R.D., J.B. Colquhoun and C.A. MallorySmith. 2006. Investigation of wheat as a trap crop for control of Orobanche minor. Weed Research 46:313-318.

Lopez-Granados, F. and L. Garcia-Torres. 1993. Seed bank and other demographic parameters of broomrape (Orobanche crenata Forsk.) populations in faba bean (Vicia faba L.). Weed Research 33:319-327.

Puzzilli, M. 1983. Tobacco broomrape and their control and some useful references to other parasite and host species. Rev. Agric. Subtropicale e Tropicale. 78:209-248.

Rao, V.M.J., M.L. Jayaswal and J.D. Ranjit. 1988. Survey and assessment of Orobanche problem in Brassica oil crops in Nepal and it's possible control options. Nepal Agricultureal Association and International Development Research Centre (IDRC) .

Sauerborn, J. 1991. Parasitic flowering plants, ecology and management. Supra-regional project, GTZ, University of Hohenheim, Institute of Plant Production in the Tropics and Subtropics. Verlag josef margraf Scientific book.

Schnell, H., K.H. Linke and J. Sauerborn 1994. Trap cropping and its effect on yield and Orobanche crenata Forsk. Infestation on following pea (Pisum sativum L.) crops. Tropical Science 34:306-314. 